\title{
Some seismologieal results and geostructural suggestions from a study of the Reggio Calabria earthquake of 16 January, 1975
}

\author{
A. Bottari (*) - F. Broccto $(*)-$ E. Lo $\operatorname{Giddice}(* *)$
}

Received on July $201 \mathrm{~h}, 1975$

Sumary. - Starting from the analytic determination of the most important parameters of the Reggio Calabria earthquake, several geostructural hypotheses are analyzed and diseussed.

The statistical hypocentre, caleulated in two separate phases for the epicentral coordinates $\left(\varphi=38^{\circ} 04^{\prime} 28^{\prime \prime} ; \lambda=15^{\circ} 38^{\prime} 55^{\prime \prime}\right)$ and for the depth $(h=10.04 \mathrm{~km})$, is consistent with an earlier macroseismic estimation.

The travel times for the first arrivals, limited to the distance interval $0 \leqslant 1^{0} \leqslant 12$ can be approximated by means of the three linear equations:

$$
\begin{array}{ll}
T=0.96+\Delta / 5.39 & 0 \leqslant 1^{0} \leqslant 1.1 \\
T=4.81+\Delta / 7.71 & 1.1 \leqslant \Delta^{0} \leqslant 6.0 \\
T=9.37+\Delta / 8.14 & 6.0 \leqslant 4^{0} \leqslant 12.0
\end{array}
$$

which can be interpreted as the travel-time curves of the direct $(P g)$ and refracted $\left(P_{n_{1}}, P_{n_{2}}\right)$ longitudinal waves.

The existence of a focal mechanism, compatible with a couple + oppositely directed force model is deduced from a study of the signs of the first impulses. This model includes faulting and displacenent with dislocation plane $N 22^{\circ} \mathrm{E}$ and inclination of $\sim 75^{\circ}$ towards $N 112^{\circ} \mathrm{E}$. Considering the focal location and our geostructural knowledge of the area involved, the Reggio Calabria carthquake can be explained by a process of tectonic distension due to the drift of the Calabrian Are and to other reliable geostructural elements. The explanation is eritically evaluated in relation to the tectonie forees involving the Strait of Messina and the voleanic zone of Etna.

(*) Istituto Geofisico e Geodetico, Universiti di Messina. $\left.{ }^{* *}\right)$ Istituto Internazionale di Vuleanologia, C.N.R., Catania 
Riassuxto - Vuovendo dalla determinazione analitica di alcuni paranetri del terremoto di Reggrio Calabria, sono analizzate e discusse aleme ipotesi geostrutturali.

lipocentro statistico, calcolato in due fasi e separatamente per le eoordinate epicentrali $\left(p=38^{\circ} 04^{\prime} 28^{\prime \prime} ; \lambda=15^{\circ} 38^{\prime} 55^{\prime \prime}\right)$ e per la profonditi $(l=10,04 \mathrm{~km})$, è consistente con uni precedente stima maerosismiea.

I tempi di tragitto dei primi arrivi, linitatamente all'intervallo di distanze $0 \leqslant 1 \leqslant 12^{\circ}$, sono approssimabili mediante le tre rette di equazioni:

$$
\begin{array}{ll}
T=0,96+4 / 5,39 & 0 \leqslant 1^{0} \leqslant 1,1 \\
T=4,81+4 / 7,71 & 1,1 \leqslant 4^{0} \leqslant 6,0 \\
T=9,37-4 / 8,14 & 6,0 \leqslant 1^{0} \leqslant 12,0
\end{array}
$$

interpretabili come equazioni delle dromocrone delle onde longitudinali lirette $(P g)$ e rifratte $\left(P_{n_{1}}, P_{n_{2}}\right)$.

Dallo studio del segno dei primi impulsi risulta poi un meccanismo focalo compatibile con un modello terieo di coppia - forze dirette ed opposte, determinanti movimento di taglio e distaceo, eon piano di dislocizione N22 $2^{\circ}$ od inclinazione di $\sim 75^{\circ}$ verso N1120l:.

In considerazione della ubicazione focale e delle conoseenze geostrutturali dell'area interessata, il terremoto di Regrgio Calabria è riconducibile al processo di distensione tettonica riferibile al moto di deriva dell Areo Calabro e al altri elementi geostrutturali attendibili. Queste ultime risultanze sono infine criticamente vagliate in relazione alle direttriei tettoniche interessanti lo Stretto di Mressina e la zona vuleaniea dell'Etna.

\section{IxtRonteTion}

The Rogrio Calabria enthquake of 16 Jamuary $1975(M=4.7)$, the origin of which was in a fulerum zone between the volomic areas of the Southern Tymhenim Sea and Dastern Sicily, oflers, among other things, the possibility of a geostructural investigation relative to some problems of great interest.

In the contest of research promoted by the Geophysical and Georletical Institute of the University of Messina, the authors of the present note deal with some problems which are mentioner in a precorling note which is, at the time of writing, in course of publication.

\section{STATISTICAI, DETERMINATION OF THE FOCAL PARAMETERS}

1 first eraluation of the focal parameters, using forty arrival times of the $P($ or $P n)$ and a statistical procedure (Bottari and Scirc, 
1973) $\left(^{6}\right)$ deriver from a well-known methorl of Caloi (1943) (14), gives the following results:

$$
\begin{array}{ll}
p=38^{\circ} 04^{\prime} 46.4^{\prime \prime} & \mathrm{N}\left( \pm 1.85^{\prime}\right) \\
\lambda=15^{\circ} 29^{\prime} 10.2^{\prime \prime} & \mathrm{E}\left( \pm 1.42^{\prime}\right) \\
h=9.63 \mathrm{~km} & ( \pm 14.26 \mathrm{~km}) \\
H=00^{\mathrm{h}} 09^{\mathrm{m}} 45^{\mathrm{s}} .2 & ( \pm 1.76 \mathrm{sec})
\end{array}
$$

where, $\varphi, \lambda, h$ and $H$ indicate, respetively, the geograplic latitude, the longitude, the depth, and the origin time. In the calculations of [1], as standard travel-times for the longitudinal waves, those of Jeffreys and Bullen (1948) ( $\left.{ }^{30}\right)$ have been userl.

As was to be expected the values of [1] present large uncertainties for $h$ and $H$. In this connexion it is well known that the statistical methor for the calculation of the four parameters of the source learls, in the case of shallow earthquakes, to different degrees of precision in the estimation of $\varphi, \lambda, h$ and $H$. In fact, while the uncertainties regarding the values of $\varphi$ and $\lambda$ are in general compatible with the physical dimensions of the focal zone and with the propagation anomalies, on the contrary the uncertainties regarding the depth value of the hypocentre appear large when observation data are not available from stations near the epicentre. The negative implications of this fact are reflected both in the origin time, which becomes rather uncertain, and in the impossibility of individualizing the crustal structures primarily involver in the seismic phenomenon. For these reasons it was decided to determine separately the epicentral coordinates $\left(\varphi, \lambda_{\text {. }}\right.$ ) and the hypocentral repth $(h)$. The value of the origin time $(H)$ was determined successively by repeating the determinations of $\varphi$ and $\lambda$, and by using for the standard times a travel-time curve of Jefireys and Bullen interpolated for the depth value previously estimated. In this case the depth value, $(h)$, having alreary been calculater, no longer figures as an unknown. These latter values of $\varphi$ and $\lambda$ were assumed as the refinitive values of the epicentral coordinates. Therefore, the procedure followed can be schematized as follows:

\section{a) Dotermination of the eqreentral coordinates}

The $P\left(o P^{\prime} n\right)$ travel-times observed in 36 stations, with $D \geqslant 200 \mathrm{~km}$, imply (with the focal depth assumer to be $h=0$ ) to allow the following as the most probable epicentre:

$$
\begin{aligned}
& \varphi=38^{\circ} 04^{\prime} 08.5^{\prime \prime} \pm 0^{\circ} .02677 \\
& \lambda=15^{\circ} 39^{\prime} 06 . .^{\prime \prime} \pm 0^{\circ} .02379
\end{aligned}
$$


b) Determination of the h!ypocentral depth

Assuming for epicentre the coordinates [2], and as provitjonal values the origin time of [1] and the focal depth $h=10 \mathrm{~km}$, and namely

$$
\begin{aligned}
& \phi=38^{\circ} 04^{\prime} 08.5^{\prime \prime} \\
& \lambda=15^{\circ} 39^{\prime} 06.5^{\prime \prime} \\
& h=10 \mathrm{~km} \\
& H=00^{\prime \prime} 09^{\mathrm{m}} 45.2^{\mathrm{s}}
\end{aligned}
$$

where the values [3] are satisfactory while [4] must be approximated. A procedure similar to that used by Nordquist (1962) (33) is userl for the calculation of the focal depth. Such a method, of which we omit the details, uses the travel times of the direct and refracted waves $\left(P_{u_{1}}\right.$ and $\left.P_{u_{2}}\right)$ in a crustal morlel consisting of homogenoous and isotropic horizontal layers.

The crustal model which we have used (Fig. 1) consists of a first layer, called superficial layer, with $h_{1}=5 \mathrm{~km}$, and the velocity of the $P$ waves, $V_{1}=3.7 \mathrm{~km} / \mathrm{sec}$; a second layer, the intermediate layer, with $h_{2}=20 \mathrm{~km}$ and $V_{2}=5.5 \mathrm{~km} / \mathrm{sec}$; and a third layer, beginning at a (lepth of $25 \mathrm{~km}$, with $V_{3}=7.8 \mathrm{~km} / \mathrm{sec}$. The values for the thickness of the layers and for the relocities of the longitudinal waves haslbeen

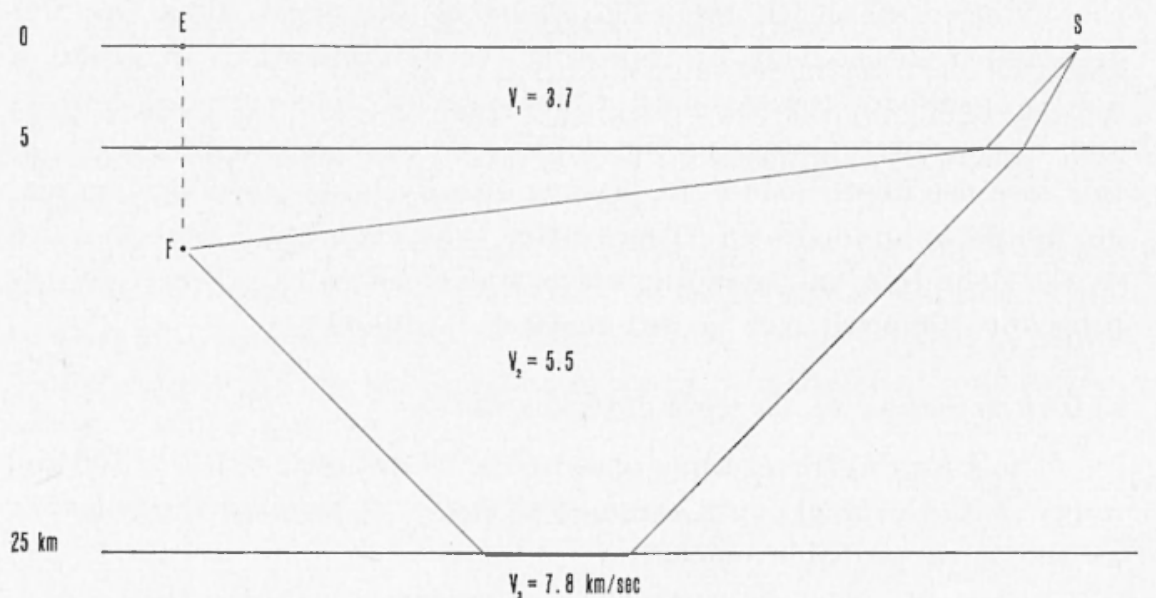

Fig. 1 - Scheme of simplified crust-model preliminarily adopted. 
estimated using results obtained, for the zone of the Southern Tyrrhenian Sea and for Sicily, from seismic exploration and from seismological investigation (Cassinis et al., 1969; Latter, 1970; Finetti e Morelli, 1972; Fahlquist, 1969; Colombi et al., 1974; Bottari and Girlanda, 1974) $(18,31,26,25,19,7)$.

Elements of the depth calculation for the eight closest stations used $(D \leqslant 160 \mathrm{~km}$ ) are presented in Table 1, with the following key: RCI = Reggio Calabria MES = Messina University $;$ SLN = Serra La Nave CAT $=$ Catania LLI $=$ Lipari PLI $=$ Panarea ACL $=$ Alicudi; FUS $=$ Fuscallo.

TABLE 1

\begin{tabular}{|c|c|c|c|c|c|c|c|}
\hline No. & $\begin{array}{l}\text { Station } \\
\text { Code }\end{array}$ & $\frac{d}{k m}$ & $\begin{array}{c}t\left(+00^{\mathrm{h}}\right) \\
\text { min sec }\end{array}$ & $\begin{array}{r}T_{o} \\
\text { sece }\end{array}$ & $\begin{array}{l}T_{c} \\
\text { sec }\end{array}$ & $\begin{array}{c}R \\
\text { sec }\end{array}$ & $\begin{array}{c}a \\
\mathrm{sec} / \mathrm{km}\end{array}$ \\
\hline 1 & $\mathrm{RCI}$ & 2.97 & $09+6.9$ & 1.7 & 2.35 & -0.65 & +0.054 \\
\hline 2 & MES & 15.77 & 49.7 & 4.5 & 4.05 & +0.45 & -0.287 \\
\hline 3 & $\mathrm{IJ} / \mathrm{I}$ & 73.78 & 59.5 & 14.3 & 14.52 & -0.22 & -1.341 \\
\hline 4 & PJII & 79.79 & 1000.4 & 15.2 & 15.55 & -0.35 & +1.451 \\
\hline 5 & SINN & 73.42 & 00.8 & 15.6 & 14.40 & $\div 1.20$ & +1.335 \\
\hline 6 & $\mathrm{C} \Delta \mathrm{T}$ & 79.39 & 01.9 & 16.7 & 15.50 & -1.20 & +1.444 \\
\hline 7 & $\mathrm{ACI}$ & 124.06 & 06.2 & 21.0 & 21.55 & -0.55 & -0.120 \\
\hline 8 & FIS & 152.31 & 09.4 & 24.2 & 25.15 & -0.95 & -0.120 \\
\hline
\end{tabular}

Key of the symbols:

$\triangle=$ epicentral distance

$\iota=$ arrival time of the $P g$ or $P n$ wave

$T_{0}=$ observed travel-time

$T_{c}=\mathrm{J}-\mathrm{B}$ standard travel-time

$R=T_{o}-T_{c}$

$a=\frac{\partial T}{\partial h}$

The calculation can be reduced to the resolution of the following system of eight equations by means of the least-square method:

$$
a_{i} \delta h+\delta H-R_{i}=v_{i}
$$

where the unknowns $\delta h$ and $\delta H$ inclicate the corrections which have to be made to the initial values of $h(10 \mathrm{~km})$ and of $H\left(00^{\mathrm{h}} 09^{\mathrm{m}} 45.2 \mathrm{~s}\right)$, respectively. $R_{i}, v_{i}$ and $a_{i}$ indicate, respectively, the dilference between 
the observed and the standard travel-time, the residual, and the partial derivative with respect to $h$, of the function representative of the travel-time eurve.

The solutions of system [5] are the following:

$$
\begin{aligned}
& \delta h=(0.71 \pm 0.20) \mathrm{km} \\
& \delta H=(-0.48 \pm 0.39) \mathrm{sec}
\end{aligned}
$$

and thus, according, to the erustal morlel arlopted, the most probable depth and the corresponding origin time, are:

$$
\begin{aligned}
& h=(10.71 \pm 0.20) \mathrm{km} \\
& H=00^{\mathrm{n}} 09^{\mathrm{m}} 44.72^{\mathrm{s}} \pm 0.39^{\mathrm{s}}
\end{aligned}
$$

The first of $[\bar{i}]$ confirms fully the depth value obtainerl by the preliminary analytic methor, as well as that estimated on the basis of macroseismic (riteria (Bottari and Lo Giudice, 1975b) ${ }^{9}$ ). However, the crustal model used may occasion some objections and learl to some hesitations because of the way it has been structured.

In particular, the data from CAT and SLN seem to be in substantial disagreement with the morlel. It was therefore decided not to use a single structural model for all the erustal sections relative to the eight stations chosen for the depth determination, but to use calculater travel-times compatible with different crustal sections. In other worls, the reference travel-times were estimater separately assuming, for each comple epicentre-station, the most appropriate crustal section. These crustal section morlels were elaborated on the basis of the work of Scarascia and Colombi (1971) (+1), Colombi et al. (1974) (19).

The resolution of system [5], this time limited to six equations because arlequate morlels are not available for the CAT and SLN sections, learls to the following results:

$$
\begin{aligned}
h & =(9.14 \pm 2.7 \pi) \mathrm{km} \\
H & =00^{\mathrm{n}} 09^{\mathrm{m}}-45.44^{\mathrm{s}} \pm 0.04^{\mathrm{s}}
\end{aligned}
$$

This last estimation of the repth is not substantially different from that in [7]. It seens possible, therefore, to locate the focus of the earthquake between a depth of 9 and $12 \mathrm{~km}$, with a average value for the hypocentral depth of $10.04 \pm 1.36 \mathrm{~km}$. 


\section{c) Determination of the origin time}

Resorting to a frequently used criterion, the determination of $\varphi$, $\lambda$, and $H$ was successively repeated with the conclition that $\hbar=10.04 \mathrm{~km}$. The procedure, applied to the rata from forty stations (with $D \geqslant 160 \mathrm{~km}$, and the standard travel-times of Jefreys and Bullen) gives the following results:

$$
\begin{aligned}
& p=38^{\circ} 04^{\prime} 28.0^{\prime \prime} \pm 1.43^{\prime} \\
& \lambda=15^{\circ} 38^{\prime} 55.4^{\prime \prime} \pm 1.24^{\prime} \\
& H=00^{\mathrm{n}} 09^{\mathrm{m}} 45.53^{\mathrm{s}} \pm 0.23^{\mathrm{s}}
\end{aligned}
$$

The [8] locate the epicentre $0.7 \mathrm{~km}$ further to the $\mathbb{N}-\mathbf{N} W$ than the precerling epicentral determination [2], which, is substantially confirmed. Is it appears in the third of [9], the value of $H$ differ's by only $\sim 0.1$ see from the value obtained by using the sections and velo-

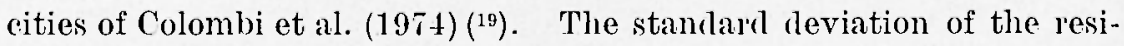
duals, for the forty travel-times used in the determination, is then 0.92 sec. Flements of the calculations are presented in Table 2 , and the definitive focal parameters of the Reggio Calabria earthquake are therefore (Fig. 2):

$$
\begin{aligned}
& \varphi=38004^{\prime} 28.0^{\prime \prime} \quad \pm 1.43^{\prime} \\
& \lambda=15^{\circ} 38^{\prime} 55.4^{\prime \prime} \quad \pm 1.24^{\prime} \\
& h=(10.04 \quad+1.36) \mathrm{km} \\
& H=00^{\prime \prime} 09^{\mathrm{m}} 45.53^{\mathrm{s}} \pm 0.23^{\mathrm{s}}
\end{aligned}
$$

\section{$P g, P n:$ 'TRAVEL-TIMES AND VeLoci'tes}

In order to emphasize the dependance of the travel-times on the epicentral distance, sixty five time-distance couples were analized. Relative to the observed first arrivals, the data does not include those times for which the difference from the corresponding Jeffreys-Bullen values are greater than $t-4$ sec.

The relation $T=T(\Lambda)$ in particular, in the clistance interval $0 \leqslant A^{\circ} \leqslant 12$, can be representer by three segments belonging to the lines of equations:

$$
\begin{array}{lrl}
T=(0.96 \pm 0.81)+\angle 1 /(5.39 \pm 0.38), & 0<1^{\circ}<1.1[11] \\
T=(4.81 \pm 0.77)+\angle /(7.71 \pm 0.10), & 1.1<1^{\circ}<6.0[12] \\
T=(9.37 \pm 0.91)+\angle /(8.14 \pm 0.06), & 6.0<4^{\circ}<12.0[13]
\end{array}
$$


TABILE 2

\begin{tabular}{|c|c|c|c|c|c|c|}
\hline No. & $\begin{array}{l}\text { Station } \\
\text { Corle }\end{array}$ & $\stackrel{1}{\operatorname{deg}}$ & $\begin{array}{l}t\left(+00^{\mathrm{h}}\right) \\
\min \sec \end{array}$ & $\begin{array}{l}T \\
\text { sec }\end{array}$ & $\begin{array}{l}I_{c} \\
\text { sec }\end{array}$ & $\begin{array}{l}\mathrm{O}-\mathrm{C} \\
\mathrm{sec}\end{array}$ \\
\hline 1 & Pl $\mathrm{R}$ & 1.822 & 1017.0 & 31.47 & 31.57 & -0.10 \\
\hline 2 & NPl & 2.914 & 1033.0 & 47.47 & 47.18 & $-1 \cdot 0.29$ \\
\hline 3 & VIAS & 3.898 & $10+7.3$ & 61.77 & 61.15 & +0.62 \\
\hline 4 & $S B S$ & 4.384 & 1052.2 & 66.67 & 68.05 & -1.38 \\
\hline 5 & $.1 \mathrm{~N}$ & 4.357 & 1053.7 & 68.17 & 67.67 & +0.50 \\
\hline 6 & TIR & 4.610 & 1056.8 & 71.27 & 71.27 & 0.00 \\
\hline 7 & $\triangle Q \mathcal{Q}$ & 4.607 & 1057.8 & 72.27 & 71.22 & +1.05 \\
\hline 8 & OII R & 5.002 & 1101.5 & 75.97 & 76.83 & -0.86 \\
\hline 9 & $\mathrm{~K} / \mathrm{N}$ & 5.252 & 1106.7 & 81.17 & 80.40 & $\div 0.77$ \\
\hline 10 & SKO & 5.908 & 1114.9 & 89.37 & 89.60 & -0.23 \\
\hline 11 & $\mathrm{VAY}$ & 6.244 & 1121.0 & $95 .+7$ & 94.38 & +1.09 \\
\hline 12 & A'TII & 6.371 & 1121.5 & 95.97 & 96.17 & -0.20 \\
\hline 13 & ATL & 6.371 & 1121.7 & 96.17 & 96.17 & 0.00 \\
\hline 14 & P'Tl. & 6.483 & 1123.5 & 97.97 & 97.76 & +0.21 \\
\hline 15 & $\mathrm{P}^{\prime} \mathrm{T}$ & 6.746 & 1128.0 & 102.47 & 101.44 & +1.03 \\
\hline 16 & $\mathrm{I}_{\mathrm{H}} \mathrm{JU}$ & 8.006 & $11+3.1$ & 117.57 & 119.09 & -1.52 \\
\hline 17 & $Z \Lambda C^{\prime}$ & 7.823 & 1143.3 & 117.77 & 116.52 & +1.25 \\
\hline 18 & KDZ & 8.267 & $11+7.9$ & 122.37 & 122.75 & -0.38 \\
\hline 19 & PRK & 8.394 & 1 I 49.2 & 123.67 & 124.52 & -0.85 \\
\hline 20 & $\mathrm{E} Z \mathrm{~N}$ & 8.499 & 1151.0 & 125.47 & 125.98 & -0.51 \\
\hline 21 & DIMI & 8.589 & 1153.5 & 127.97 & 127.23 & +0.74 \\
\hline 22 & Ist) & 8.904 & 1156.7 & 131.17 & 131.57 & -0.40 \\
\hline 23 & נינ & 8.836 & 1157.0 & 131.47 & 130.64 & +0.83 \\
\hline 24 & $I \% M$ & 9.145 & 1200.3 & 134.77 & 134.91 & -0.14 \\
\hline 25 & DEV & 9.484 & 1205.5 & $\mathbf{1} 39.97$ & 139.58 & +0.39 \\
\hline 26 & MLIS & 9.822 & 1208.9 & 143.37 & 144.25 & -0.88 \\
\hline 27 & $\mathrm{D} M \mathrm{~K}$ & 10.015 & 1211.0 & 145.47 & 146.90 & -1.43 \\
\hline 28 & Jos & 11.006 & । 226.9 & 161.37 & 160.38 & +0.99 \\
\hline 29 & EIL & 11.420 & 1231.0 & 165.47 & 166.09 & -0.62 \\
\hline 30 & s'TU! & $11.6+6$ & 1236.0 & 170.47 & 169.19 & +1.28 \\
\hline 31 & BSF & 11.706 & 1236.8 & 171.27 & 169.99 & +1.29 \\
\hline 32 & PRU & 11.937 & 1237.5 & 171.97 & 173.15 & -1.18 \\
\hline 33 & $\mathrm{CDF}$ & 11.979 & 1238.0 & 172.47 & 173.71 & -1.24 \\
\hline 34 & CILL & 13.366 & 1256.0 & 190.47 & 192.14 & -1.67 \\
\hline 35 & TIo & 20.155 & $1+22.7$ & 277.17 & 277.15 & +0.02 \\
\hline 36 & NUR & 23.167 & 1453.0 & 307.47 & 307.52 & -0.05 \\
\hline 37 & KER & 25.587 & 1516.7 & 331.17 & 330.78 & +0.39 \\
\hline 38 & SIII & 31.785 & 1610.6 & 385.07 & 386.62 & -1.55 \\
\hline 39 & KIC: & 36.596 & 1654.4 & 428.87 & 427.90 & +0.97 \\
\hline 40 & $1, W I$ & 41.916 & 1739.0 & 473.47 & 472.11 & +1.36 \\
\hline
\end{tabular}

Key of the symbols: $A=$ epicentral distance; $t=P$-wave arrival-time; $T_{o}=$ observed travel-time; $T_{c}=\mathrm{J}-\mathrm{B}$ standard travel-time; $0 . \mathrm{C}=$ traveltime residual. 


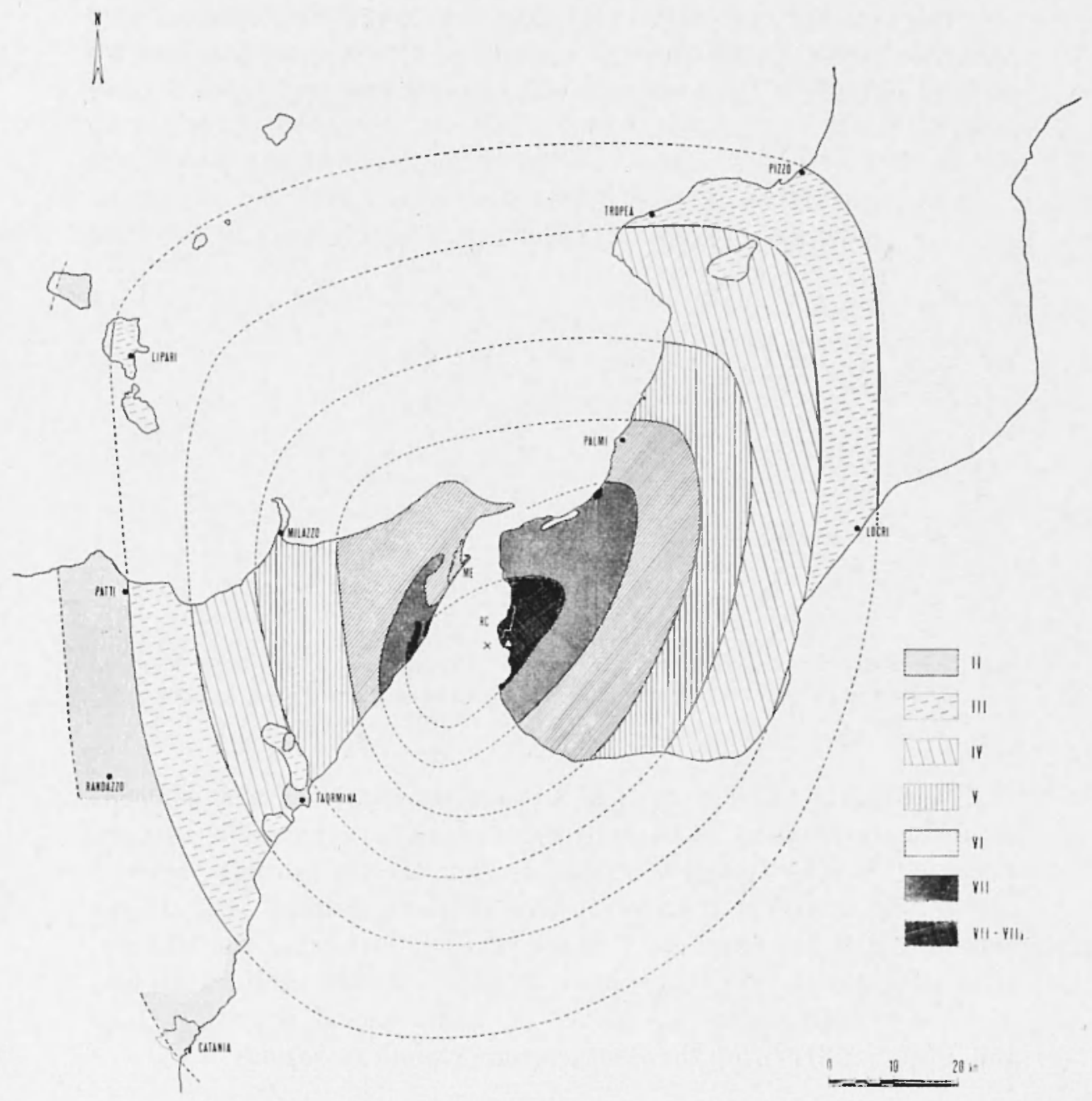

Fig. 2 - Relieved isoseiste-map where the eross and the open triangle indicate respectively the macroscismic and the analytical epicentre.

which can be interpreted as the travel-time equations (Fig. 3) of the direct waves $(P g)$ and of the refracted waves $\left(P_{n_{1}}, P_{n_{2}}\right)$.

The velocity of $5.39 \mathrm{~km} / \mathrm{sec}$ for the $P g$ (eq. [11]), which agrees with the values obtained by Latter $(1970)\left({ }^{31}\right)$ for the Aeolian Island zone, also agrees with the average of those proposerl by several researohes (Cassinis et al., 1969; Scaraseia and Colombi, 1971; Finetti and Morelli, 1972; Colombi et al., 1974) $(18,44,26,19)$ for various crustal sections of Sicily, Calabria and Southern Tyrrhenian basin. 
The velocity $7.71 \mathrm{~km} / \mathrm{sec}$ (eq. [12)], which an be attributed to a refraction phase agrees with the velocity of $7.78 \mathrm{~km} / \mathrm{sec}$, obtained by Bottari and Girlanda (1974)( $\left.{ }^{7}\right)$, for the Middle Western Meditermanean basin.

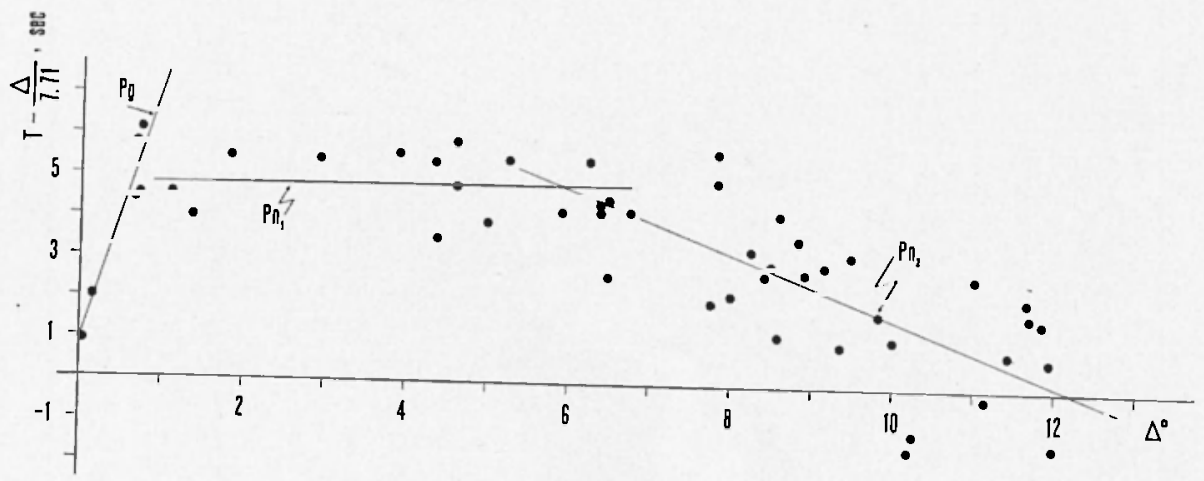

Fig. 3 - Reduced travel-time curves for $T_{0}^{\prime}$ waves $(V=5.39 \mathrm{~km} / \mathrm{sec})$ $P_{n_{1}}$ waves $(V=7.71 \mathrm{~km} / \mathrm{sec})$ and $P_{n_{2}}$ waves $(V=8.14 \mathrm{~km} / \mathrm{sec})$.

Finally, the velocity value of $8.14 \mathrm{~km} / \mathrm{sec}$ (eq. [13]), also confirms an earlier estimation $(8.15 \mathrm{~km} / \mathrm{sec})$ obtained by the same authors. Because this velocity values is deduced from the travel-times observed prevalently at the stations of Midclle Southern Furope (Fig. 4), we believe that it expresses the $P$-wave velocity, just below the Mohorovicic discontinuity, for this region. In arldition, this result recalls also the $P n$ velocity-values mentioned in seismological literature (Iosif and Iosif, 1973) (29) for the Southeastern European region.

\section{Geostiructirat context}

The geological literature concerning Sicily and Calabria has, in a variety of ways, been characterized by overthrust morlels which have supplanter the earlier morlel of total autochtony which was given by Cortese $(1882 ; 1895)\left({ }^{20,21}\right)$. This geologist was the first to indicate the Messina Straits fault.

Limanowski (1913) (23), following tectonic morlels with great recumbent folds, consirlers the whole Calabria-Peloritani Complex as a re- 
versed nappe carried up over the Sicilide nappes. The Straits of Messina, for this author, would be therefore a "cuesta" furrow, due to the erosion of the phyllite nucleaus of the syncline between the normal sequence of $A$ spromonte and the reversed sequence of the Peloritani mountains, and the fault suggested by Cortese would be limit of the nappe. In the light of morlern morlels, based on overthrusts, this explanation of the origin of the Straits is no longer acceptable.

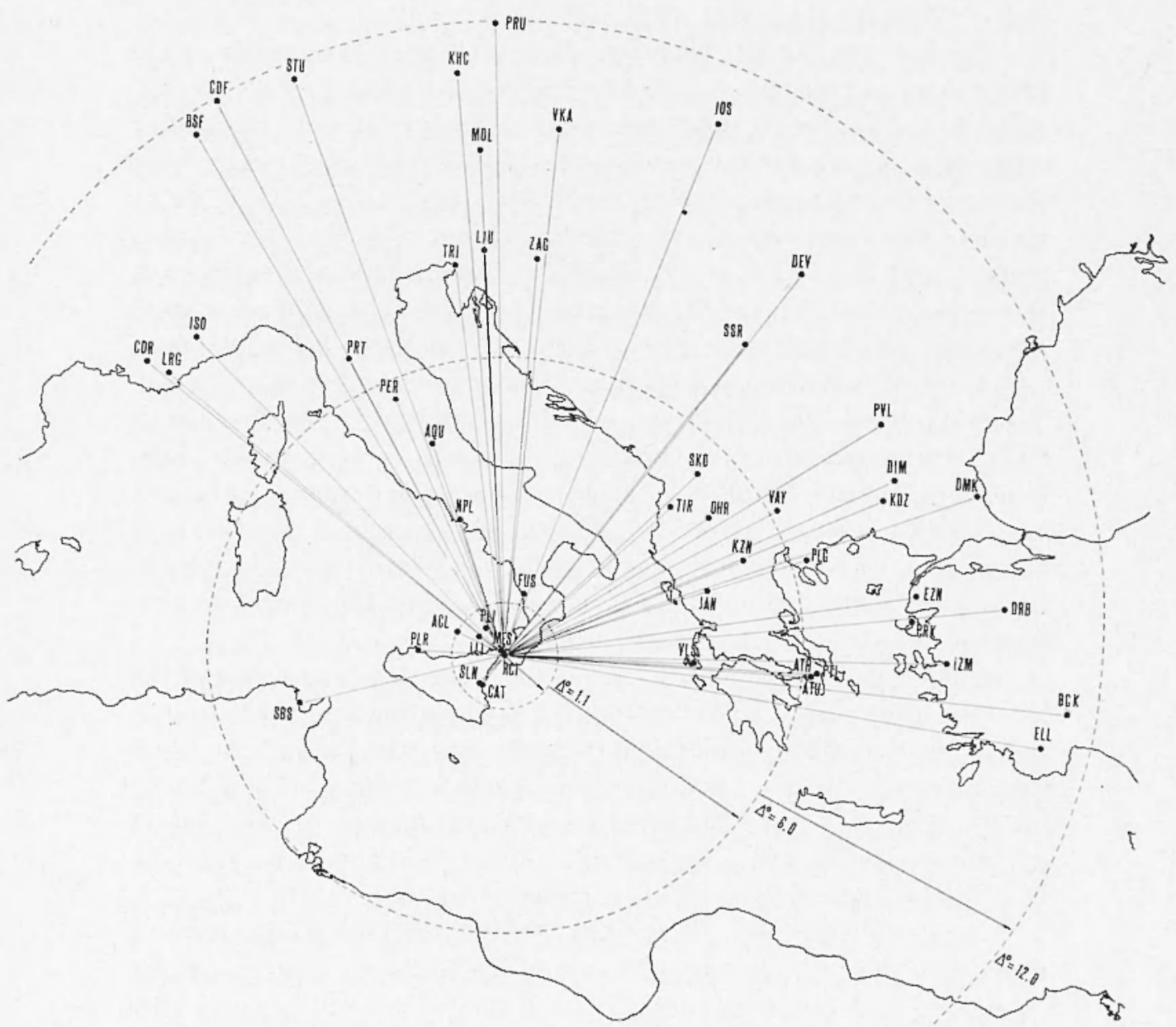

Fig. 4 - Map of Middle-Southern Europe. The abbreviations indicate the seismic stations used in order to determine the $P$-wave travel-time curves. 
Trevisan (195-4)( $\left.{ }^{(4)}\right)$, in a stuly of Quaternary tectonic movements, arcues that they are related to other, previous movements, of which they are the eontinuation. Same anthor diviles Sicily into four separate units - of these the two eastern zones are the Peloritani and the Ragusa platean - and the second of these two units is considered to be rlivided from Western Sicily by a spstem of faults with NI-SW strike and active at least from the Miocene to the Quaternary period. Trevisan also points out that the higher level of seismic activity of sicily (ul) to the north-west extremity) and the volcanic activity of the Iblei and of Etna lie alongr this alignment.

Beneo (1919 and following) $(2,3)$ does not accept the models of the overthrusts and recognizes only the gravitational gliding of the "Tarieyated shales", the only allochthonous formations relative to the Alpine orogenesis. In his schematic map of Italy, he incliviruates two systems of large faults: an earlier fault transversal system, with a NE-SW strike which dates from before the overthrust, and a second Appeninian system, with a NW-SE strike, which is subsequent to the overthrust. Beneo recognizes that the Straits have a tectonic origin, and are located along the principal transversal system. In adlition, he individuates within the Messina Straits a third and less important system and which has E-W strike. This direction, which we also find in the Tyrrhenian basin (the voloanism of Ustica and Palinuro), is very ancient and, according to Selli $(1970)\left({ }^{15}\right)$, has been re-activated successively.

Vecelia $(1956)\left({ }^{17}\right)$, consillers that the fault system in the Straits is active, and, given the continuity of positive isostatic anomalous zones, both in the Peloritani and Calabrian areas, favours the idea of vertical movements alongr a large fault-system.

Glangeaud $(1952 \mathrm{a}, \mathrm{b})\left({ }^{27,28}\right)$ formulates a geo-dynamic model of the - Mediterranean area, by putting forward the hypothesis of the existence in the Mesozoic of two continental blocks, one African and the other European, divided by a Sial-free-zone. In this tectonic scheme, Sicily and Calabria (the latter detached from the Apennines in the zone of Sangineto) are clockwise turned and, shifted South, because they are part of the exlge of the African continental block.

Ogniben $(1960,1966,1971,1973)\left({ }^{34,35,36,37}\right)$, taking up Limanowski's ideas, develops an Alpine type structural morlel for the centre-sonthern Apennines and for Sicily; this is based on the overthrusts of entire "complexes", and each of these is, in turn, a piling up of several nappes. According to this model, he recognizes in the Calabria-Peloritani massif the "Calabride complex", which is constituted, in turn, of four nappes 
which began overthrusting between upper Eocene and lower Oligocene. The positioning of the whole "Calabride Complex", paleogeographically the most internal, took place in the last orogenic phase and was completed before the beginning of the Miocene. On the basis of gravimetric maps and on the basis of the position of the isostatic uplift axes, he emphasizes the probable Pleistocenic nature of the great transcurentfault of the faulting zone Gela-Catania-Messina-S. Enfemia, with anticlockwise transcurrent movement.

Most recently Caire $(1970,1973 \mathrm{a}-\mathrm{b}, 1974)(10,11,12,13)$ who does not seem to deviate much from the structural soheme proposed by Glangeaud, has put forward a tectonic model which it would be useful to examine in some detail. On the basis of various data and observations including the demostrated anticlockwise rotation of the Corsican-Sardiniam block, Caire proposes that, in the Mesozoic, the Tyrrhenian basin was less closed and therefore more typical than the present Tyrrhenian arc. He clisplaces, with a clockwise rotation towards N W, both the Corsican block and, in order, the Calabria-Peloritani massif and central Sicily, obtaining thereby an hypothetieal linkage, though a very flat are line, of the Kabyli (North African massif), the Calabria-Peloritani massif, and the Tuscan lidge. From the Mesozoic onwards the gradual closmre of the Tyrrhenian are would have ocemred, according to this hypothesis, because of the drift of the Calabrian-sicilian Complex towards E-SE. If, as seems clear on the basis of a variety of evidence, the tendency of the Tyrrhenian are is to continuing closure due to the E-SE drift of the Calabria-Peloritani arc (Ritsema, 1969) ${ }^{(38)}$, one should expect, in our opinion, the continuance o fa distensive process in the Messina Straits with a fanshaped opening towards the Sonth. In addition, for Caire, the helicoidal distribution of the Mpine structures in the Mediterranean area, is to be considered the image of a spiral tectonic model. Such a tectonic pattern is clue to two joined radial bundles ("gerbes") of curving and divergent faults, active at least from the Oligocene onwards. The convergence point of the principale bundle is in the West Paduan Plain; this bundle consists of transcurrent anticlockwise movements. According to Caire, the fault passing through the Messina Straits and the Ragusan platean belongs to this fault system. The present authors believe that, in addition, the faults of the clockwise fault system, which converge in Sardinian-Balearic basin, also cross the Messina Straits in a more-or-less NW-ST direction. The faults of this system although in general less evilent than those of the first system, are more developed in the Ragusa plain and in the Palermo mountains. 
Recently, l'Amico et al. (1973) $\left.{ }^{(22}\right)$ have described the Messina Straits in a way which is compatible with vertical distensive movements extending in various directions (NE-SW, North-Sonth, East-West). These authors, comparing the metamorphic rocks on the two shores by means of petrographic parameters, esclude the possibility of transform movements of some importance along the NE-SW direction. In contrast, along the directions $\mathrm{E}-\mathrm{NE}$ and $\mathrm{W}$-SW, horizontal movements are possible and in any case compatible with their observations.

Finally, in the last few years the overthrust morlels have been joined by global tectonics. According to the supporters of the latter, following the approch of the two continental blocks of Europe and Africa (including Sicily) a subduction of the oceanic crust began which continued until the midlle Hiocene when the encounter of the two blocks was accompanied by the formation of the Peloritani monntains (Ritsema, 1971; Caputo et al., 1970; Finetti and Morelli, 1972; Barberi et al., 1973; Bottari and Jo Giudice, 1975a) $\left({ }^{39,16,26,1,9}\right)$. The subluction uncler the Calabrian are seems to be continuing still. The impact of the ywo continental blocks occurred in different phases, progressing in an anticlockwise direction from West to East. In the lower Miocene, East Sicily was the limit between the zone of collision of the continental blocks and the zone of the subduction of the oceanic crust under the Calabrian arc. Sicily, therefore, was involved in a local distentive tectonics perpendicular to the direction of movements of the oceanic crust. The origin of the Messina Abyssal Plain and of the Messina Cone, which begins in the south of the Straits, is therefore based on this distensive tectonies, opening up in an anticlokwise direction.

The basic character of the voleanism in East Sicily is, in fact, a clear inclication of a distensive tectonics (Rittmam, 1967, 1973; Romano and Villari, 1973) (40,41,42). This voleanism is present prevalently along tectonic axes oriented NE-SW and NW-SE, both of these axes being present in the Messina Straits. In addition, the evolution over time of this voleanism is also favourable to the model of a distensive tectonics. In fact, there is, between the Miocene and the Quaternary, a shift of the voleanism from the South (Tblei) towards the North (Etma) and this is a clear indication of a distensive opening towards the North. Moreover, in the volcanic zone of Etna in a time perion which is, in geological terms, very short, there has been a shift from the East towards the West of volcanic activity, and this is an arditional indication of a distensive opening, in the Cone and in the Nessina Batial Plain. 
Interesting results are also available from geophysical studies. From deep seismic refraction, the crustal section of the two sides of the Straits prove to be almost identical.

In a study of the seismic activity of the Straits over the twenty year period 1950-1969, Bottari (1971) $\left(^{5}\right)$ obtained a distribution of the epicentres where the principal seismic foci are found to be located more-or-less along a line travelling in a NE-SW direction. There seem also to be secondary epicentral distributions in a direction which is more-or-less perpendicular to the preceding line.

From the oceanographic seismic reflection explorations (Finetti and Morelli, 1972) ( $\left.{ }^{26}\right)$ it seems that the African continental shelf continues beyond the Messina Straits and the Ionian Sea up to the southern edge of the Calabrian are, and includes the Ragusa massif. From these explorations it is also clear that the Ifrican continental shelf, due to a system of subvertical direct faults along the eastern erlge of Sicily, is still subsiding under the Ionian Sea.

The first result of geodimetric measurements carried out between the two shores of the Messina Straits (Capnto et al. 1974) (17) gives cautious support to the idea of a northward drift of Sicily and an anticlocliwise rotation of the Calabrian are.

From above summary, it is evident that the recent literature on the subject is almost unanimous in holding that the Messina Straits is the result of a tectonic mechanism which is still active. Ideas differ, however, as to the precise mechanism of the movements. In the most wide spread theories appear to be:

i) anticlockwise transcurrent

ii) vertical

ii) southward anticlockwise fan-like opening.

FARTHQ⿻上AKE MECHANISM

The totality of the signs (compression, dilatation) observed in twenty-seven stations located around the epicentre were used in order to investigate the focal mechanism of the Reggio Calabria earthqualie. In general, the data relative to the I, the II and the IV quadrants are well distributer.

Transfering the station points to equatorial stereographic projection, following a well known method (Di Filippo, 1950) (23) the circle 
projection of the intersection of the two nodal planes with the earth's surface were traced (Fig. 5). These planes are clefined as follows:

a) strike plane $\mathrm{N} 22^{\circ} \mathrm{E}$ with dip angle of $\sim 75^{\circ}$ at $\mathrm{N} 112^{\circ} \mathrm{E}$.

b) secondary plane $\mathrm{N} 112 \circ \mathrm{E}$ dipping $\sim 90^{\circ}$.

The sign distribution of the first impulses registered on the vertical component (the only data in our possession) is compatible with the following models (Bessanova et al., 1960) $\left(^{4}\right)$ :

1 - Couple determining movement of the sides along the rupture plane.
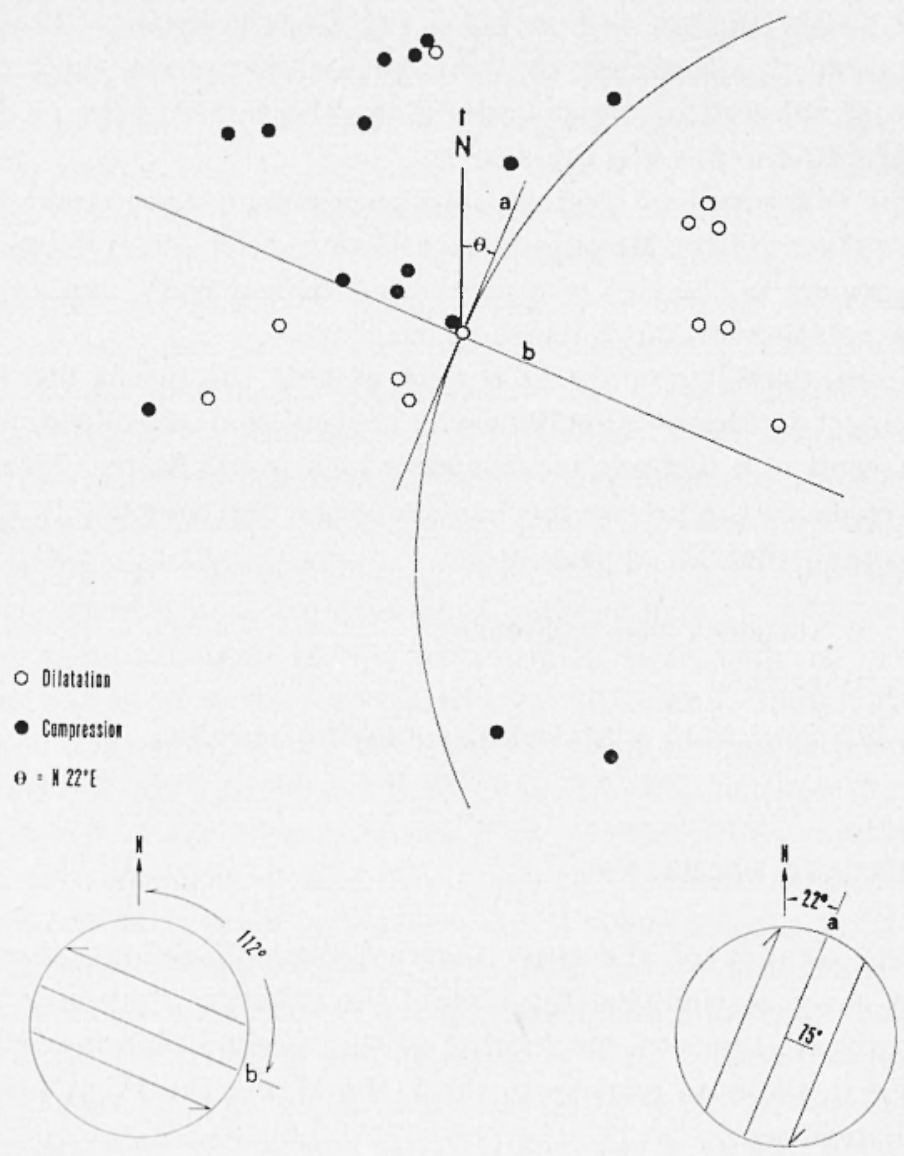

Fig. 5 - Graphical clistribution of the first motion signs together with some clements of earthquake mechanism. " $a$ " and " $b$ " indicate the nodal planes. 
2 - Double couple determining simultaneous shear along two perperlincular planes.

3 - Superposition of couple and oppositely directed forces determining symmetrical combination of shear and break-ofl.

Given the macroseismic: axes recognized (Bottari and Iso Giudice, 1975) $\left({ }^{9}\right)$, given the prevalent orientation (NE-STV) of the horizontal acceleration observed at Reggio Calabria, and given our geostructural and morphological knowlerlge of the Messina Cone, one can exclude the possibility of a focal mechanism of the type according with morlel 2 (two perpendicular couples). The possible displacement, which in any case is prevalently horizontal, is therefore referable to a strike plane N22 ${ }^{\circ}$ with a rlip angle of $\sim 75^{\circ}$ at N112 E, according to a model of type 1 or type 3.

\section{RESUITS AND DISCUSSIOX}

The results of the present study can be summarized and discussed.

The epicentre of the Reggio Calabria earthquake of 16 January, 1975 can be located by macroseismic and analytic means some kilometers South of the Calabrian city (Fig. 2). The refined analytic determination of the epicentre:

$$
\varphi=38^{\circ} 04.46^{\prime} \pm 1,43^{\prime} ; \lambda=15^{\circ} 38,92^{\prime} \pm 1,24^{\prime}
$$

and the other source parameters have, for the first time, been obtained for a seismic event originating in the Messina Straits. The focal lepth, which is relatively modest, differs only a little in the two estimations, the macroseismic (12.5 $\mathrm{km}$ by Bottari and Jo Giudice, 1975b) and the analytic $(10.0 \mathrm{~km})$.

In examination of the travel-times for the first arrivals $\left(I^{\prime} g, I^{\prime} n\right)$ permitted an accurate cletermination, this too for the first time for an Straits earthquake, of the travel-time curves of the $I^{\prime} y$ and the $P \prime n$ waves. Using the relationship $T=T(A)$, the $P y$ velocity $(V=5.39$ $\mathrm{km} / \mathrm{sec})$ and the $P$ n velocities $(T=7.71 \mathrm{~km} / \mathrm{sec} ; Y=8.14 \mathrm{~km} / \mathrm{sec})$ have been determinerl. The velocity value for the $I$ 'g waves agrees substantially with the results of seismic explorations conducted in the areas adjacent to the Straits. In ardition the velocity values of the $P_{n_{1}}$ waves and $P_{n_{2}}$ waves confirm and seem to extend the applicability of a precerlent estimation of Bottari and Cirlanda (1974)( $\left.{ }^{7}\right)$. 
The rlistribution in qualrants of the first motion signs observer at twenty-seven stations is compatible with a prevalently horizontal movement in the focus.

In a precerling macroseismic study $\left(^{9}\right)$ we have observed that the general trend of the isoseismal lines reveals several preferential axes (NE; SSW; NW), and that, in particular, two structural characteristics diflerentiate the northern part (aligned on the direction liNE-WSW) from the souther'n part of the Straits (the Messina Cone).

Then, various considerations concerning the distribution of the first motion signs, the morphological and geostructural context, and the results of macroseismic studies, indicate two possible focal mechanism morlels, laving the dislocation plane N220 with dip angle of $\sim 75^{\circ}$ at N1120. The two possible models are, first, the clockwise couple model, which causes a symmetrical displacement in relation to the plane of rupture, with movement of the sicles along this plane in opposite directions, and, second, the clockwise couple superimposed on oppositely directed forces, which cause the symmetrical combination of shear and break-ofl. Given the location of the focus, at the apex of the Messina Cone, given the distensive tectonies of the Cone, and given the drift of the Calabrian are and other elements of the structural context which we have alrearly describerl, the second model seems to be physically the more realistic. In this case, the direction of the forces which determine the break is near the direction of the Calabro-arc-rlift, and in aldition the orientation and the dip angle of the dislocation plane are signilicantly similar to those of the faults which Finetti and Morelli (1972) (26) discovered along the Ionian continental slope of Sicily (Cape Passero).

From what has alrealy been said, it is therefore evident that the Strats of Messina is involved in varions tectonic forces. This is true, even if it is not easy to irlentify which of these tectonic forces are to be considered the most active, and so what type of mechanism. We therefore believe it is unrealistic to consirler the displacment mechanics to be single and irreversible in time. It is unrealistic also because, a fanlt system may be reactivater by a force distribution diflerent from the primary distribution which cansed the fault system, even with possibilty of a reversal of the direction of the initial movement. 


\section{REFERENCES}

(') Barberi F., Gasparivi P., Innocesti F., Villari L., 1973. - Tolcanism of Southern Tyrrhenian Sea and its geodynamic implications. "J.G.R.", 78, pp. $5221-5232$.

$\left({ }^{2}\right)$ Bexeo E., 1949. - Tentativo di sintesi tettonica dell' Italia peninsulare ed insulare. "Boll. Soc. Geol. Ital.", LXIII, pp. 67-80.

$\left({ }^{3}\right)$ Bexeo E., 1961. - Piano di studi nello Stretto di Messina per il collegamento della sicilia con la Calabria. "Ricer. geol.", I.R.E.S., Palermo.

(4) Bessanova E. N., Gotsadze O. D., Kenlis-Borok V. I., Kirhlova I. V., Kogax s. D., Kikhtikova T. I., Malinovskala I. N., Paulova G. I., Sorskil A. A., 1960. - Investigation on the mechanism of earthquakes. "A.G.L.", N.I.

$\left(^{5}\right)$ BotTARI A., 1971. - Lialliviti sismica nello strello di Messina nel ventennio 1950-1959. "Ann. Geofis.", XXIV, pp. 103-133.

${ }^{(6)}$ BOTTARI A., SCIRE II., 1973. - The statistical determination of hypocentral parameters by small dimensions computers. "Riv. Ital. Geof.", XXII, pp. $41-46$.

(7) Bottani A., GiRLANDa A., 1974. - Some results for the middle western Irediterranean basin from the study of Pn waves. "Bull. Seism. Soc. Am.", 64, pl. $427-435$.

$\left(^{8}\right)$ BotTari A., Lo Giunice E., $1975 a$ - On the P-wave velocity and platetectonics implications for the Tyrrhenian deep earthquake zone. "Tectonophysies", 25, pp. 187-200.

$\left({ }^{9}\right)$ BotTani A., Lo Giunice E., 1975b. - Il terremoto di Reggio Calabria del 16 gemnaio 1975. “Ann. Geofis.", XXVIII, 2-3.

$\left.{ }^{10}\right)$ CAIRE A., 1970. - Tectonique de la Méditerranée centrale. "Ann. Soc. Geol. Nord", XC, pp. 307-346.

(11) (AIRE A., 1973a - The Calabro-Sicilian Arc. "Gravity and Tectonies", Editor Kees A. De Jong Seholten R., published by J. Wiley \& Sons.

$\left.{ }^{(12}\right)$ Cank A., 19731). - Sur quelques caractéres et propriétés des gerbes de failles. "Am. Scient. Univ. Besançon", Geologrie, 3, 20, pp. 55-71.

${ }^{\left({ }^{13}\right)}$ Cande A., 1974. - Tectonique spirale en Méditerranée centrale. "C. R. Acal. Sc. Paris", tome 278, ser. D, pp.

(14) Cator P., 1943. - Garatteristiche sismiche fondamentali dell'Europa centrale. "Boll. Soc. Sism. Ital.", XL, pl. 3-34.

$\left({ }^{15}\right)$ Calor P., 1952. - Struthura geologico sismica dell'Europa centro meridionale, dell'Lalia e del ILediterraneo centro oceidenlale, quale risulla da recenti ricerche compiute in. Italia, "Ann. Geof.", V, pl. 507-518.

$\left.{ }^{16}\right)$ Caputo II., Paxza G. F., Postpischil D), 1970. - Deep structure of the Mediterranean basin. "J. G. R.", 75, pp. 4919-4923. 
(17) Capeto M., Follosi G., Peri L., l xavexpoli M., 1974. - Geodimetric control across the Straits of Messina, "Geophys. Journ. Res. Astr. Soc.", 38 , pp. $1-8$.

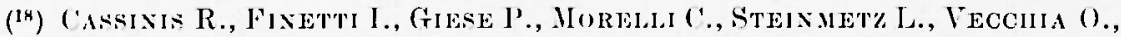
1969. - Deep seismic refraction research on Sicily. "Boll. Geof. 'Teor'. Appl.", 11, pp. 140-160.

(19) Colombi B., Guerra l., Luoxgo G., Scarascia S., 1974. - Risulali preliminari del profilo sismico a rifrazione profonda: penisola SalentimaIsole Eolie. Preprint for the A.G.I. symposium, Rome.

${ }^{(20)}$ ConTEsE E., 1882. - Sulla formazione dello Strello di Messina. "Boll. Reor. Com. Ital.", III, pp. +-29.

(21) CORTESE E., 1895. - Geotettonica e sismologia della deserizione geologica della Calabria. "IIem. IDeser. Carta Geol. d'Italia", IX, pl. 30-62.

(22) I'dinco C., Mressixa A., Pugisis G., Rotetura A., Russo s., 1973. - Confromli petrografici nel cristallino delle due sponde dello Strello di Messina. Implicazioni geodinamiche. "Boll. Soc. Geol. Ital.", 92, pp. 939-953.

(23) J) Finppo D., 1950. - Sulla rappresentazione in superficie della nalura dinamica di una scossa all ipocentro. "Ann. (icofis.", III, 2, pp. 264-279.

(21) Di Finppo D., Marcela. L., 1952. - Mromocrone per lerremoli vicini e velocitic delle onde nell Italia centrale. "Ann. Goofis.", V, pp. 293-310.

${ }^{25}$ ) FAHI.QUIST D. A., IIERSEY J. B., 1969. - Seismic refraction measurements in the ITestern Mediteranean Sea. "Bull. Inst. Océan.". Monaco, 67, No. 1386.

${ }^{(26)}$ Finetri I., Morenu C., 1972. - Wide scale digital seismic exploration of the Medilerranean Sea. "Boll. Grofis. Teor. Appl.", XIV, pp. 291-342.

${ }^{(22)}$ Giavrigaud I., 1952a. - Les phenoménes géphysiques el l'écolution de la Médilerranée occidenlale. "Ann. Géophys.", 8, 1, pp. $112-132$.

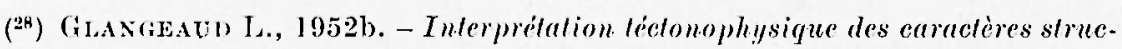
turaur et paliogéographiques de la Méditerranée occidentale. "Bull. Soce. Giol." France, ser. 6, 1, pp. 735-762.

(29) IosIF 'Т., IosIF S., 1973. - Date asupra struchurii seorlei si mantalei te restre. "St.cer. gool., geofiz., geograf.", seria geofizica, 11, 2, pp. 203-219.

(3i) JEFrkeYs II., Buthex K. E., 1948. - Seismological Iables. Office of the British Association, Burlington House, W. I, London.

(31) LatTTER J. II., 1970. - Near surface seismicity of luleano, deolian Islands, Sicily. Symposium on Volcanoes and their Roots, Oxford, September 1969.

(32) Iamasowsk M., 1913. - Die grosse halabrische Decle. "Bull. Int. Aead. sc. Cracovie", Cl. Se. Math. Sat., S.A., 6 A, pp. 370-385.

(33) Nornquist J. M., 1962. - I special-purpose program for earthquake location with an electromic computer. "Bull. Scism. Soce Am.", 52, pp. 431-437.

(31) Ocximex L., 1960. - Nola illustration dello schema geologico della sicilia nordorientale. "Riv. Miner. Sicil. Palermo", XI, Pp. 183-212.

(:5) OGxmex I., 1966. - Lineamenti idrogeologici dell Etma, "Riv. Minor. sicil." Palermo, XVII, pl. 151-17t. 
(36) Orvinsx L., 1971. - Tethonira della sicilia e della Culabria. "Boll. Ace. Gioenia sc. Nat.", Catania, ser. IV, XI, pp. It-26.

(37) Ocxinkx L., 1973. - Sehema geologico della Calabria in base ai dati odierni. "Geologica Romana", XII, pp. 243-585.

$\left({ }^{38}\right)$ Ritsema A. R., 1969. - Seismic-tectonic implications of a review of European earlhquake mcchanism. "Gool. Rund.", 59, pl. 36-56.

${ }^{(39)}$ Ritsina A. R., 1971. - Notes on plate tectonics and aro movements in. the Mediterranean region. "Proc. Eur. Seism. Comm.", Laxemburg.

(10) Ritrmani A., 1967. - Die Bimodalikal des Tulkanismus und die Merkunft der Magmen. "Geol. Rund.", 57, pp. 277-295.

(") Ritwuas A., 1973. - Structure and evolution of Mount Etma. "Plit. Trans. R. Soc.", London, A. 274, pl. 5-16.

(52) Romaxo R., VILLari L., 1973. - Caratteri petrografici e magmatologici del vuleamismo ibleo. "Rend. Soe. Ital. Min. Petrog.", XXIX, pp. 453-485.

(13) RYax W. B. F., Heszex B. C., 1965. - Ionian Sea Submarine Canyons and the 1908 Messina Turbidity Current. "Geol. Soc. Am. Bull.", 76, pp. $915-932$.

(4) Scarascia S., Colonbi B., 1971. - Interpretazione preliminare del profilo sismico a rifrazione profonda in C'alabria. "C.N.R., Lab. Geofis. Jitusf.", Milano, pp. 35.

(15) Sxu.. R., 1970. - Oenni morfologici generali sul hare Tirreno. "Giorn. Geologr.", XXXVII, pl. 5-24.

(46) Truvisax L., 1954. - Les mourements tectoniques récent en sicile. IIypothèses et problèmes. "Greol. Rund".' 43, p1. 207-221.

(4ī) VECCHA 0., 1956. - La Sicilia e le aree circostanti, lineamenti geofisici e geologia profonda. "Boll. Soc. Geol. Ital.", 75. pl. 61-87. 